\title{
Molecular characterization of a Xylanase-producing fungus isolated from fouled soil
}

\author{
Punniavan Sakthiselvan, Balakrishnan Naveena, Nagarajan Partha \\ Department of Chemical Engineering, A.C. College of Technology, \\ Anna University Chennai, Chennai, India.
}

Submitted: October 27, 2013; Approved: April 17, 2014

\begin{abstract}
Xylanase (EC 3. 2. 1. 8), hydrolyzes xylo-oligosaccharides into D-xylose and required for complete hydrolysis of native cellulose and biomass conversion. It has broad range of applications in the pulp and paper, pharmaceutical and Agri-food industries. Fifty fungal species were isolated from the fouled soil around an oil refinery and screened for the production of xylanase enzyme by enrichment culture techniques. The isolated fungal strain was identified as Hypocrea lixii SS1 based on the results of biochemical tests and $18 \mathrm{~s}$ rRNA sequencing. The phylogenetic tree was constructed using the MEGA 5 software. Further, Hypocrea lixii SS1 was tested for the ability to utilize the sunflower oil sludge (waste from the oil industry) as the sole carbon source for xylanase production. The growth characteristics of Hypocrea lixii SS1 were also studied and maximum growth was found on the $7^{\text {th }}$ day of incubation. The fungus showed a remarkable xylanase production of $38.9 \mathrm{U} / \mathrm{mL}$. Xylanase was purified using a combination of $0-50 \% \mathrm{NH}_{4} \mathrm{SO}_{2}$ precipitation, DEAE-sepharose and Sephacryl S-200 chromatography. Single peak obtained in RP-HPLC confirms the purity of xylanase. Further the enzyme produced was affirmed as xylanase with its molecular weight (29 kDa) using SDSPAGE.
\end{abstract}

Key words: fungal isolate, growth kinetics, Hypocrea lixii SS1, fermentation, xylanase, purification.

\section{Introduction}

Lignocellulosic wastes are generated from agricultural practices and industrial processes, peculiarly from agro-allied industries such as breweries, paper-pulp and textile industries throughout the world. These wastes generally accumulate in the environment, thereby causing pollution (Okafor et al., 2007). However, these wastes are biodegradable and can be converted into valuable products such as biofuels, chemicals and cheap energy sources for fermentation and ameliorated animal feeds (Howard et al., 2003). Ligno-cellulosic wastes refer to plant biomass wastes that are mainly composed of lignin, cellulose and hemicelluloses. They may be grouped into different categories such as wood residues (including sawdust and paper mill discards), waste paper and agricultural residues including straw, bagasse, domestic wastes (lignocellulose waste), food industry residues and municipal solid wastes (Mtui, 2009). Due to their abundance and renewability, there has been a great deal of concern in utilizing lignocellulosic wastes for the production and recovery of many valueadded products (Pandey et al., 2000; Foyle et al., 2007).

Hemicellulose is the second most abundant plant fraction available in nature after cellulose present agroindustrial wastes. It consist of a mixture of hexosans, pentosans and their monomers are useful in the production of different antibiotics, animal feed and fuels. Xylan is the most abundant of the hemicelluloses which has a linear backbone of $\beta$-1,4-linked d-xylopyranose residues which is further substituted, depending on plant sources to a varying degree with glucuronopyranosyl, 4-0- methyl-d-glucopyranosyl, $\alpha$-l-arabinofuranosyl, as well as linked to feruloyl and coumaryl components of lignin (Shallom and Shoham, 2003). Biodegradation of xylan requires the action of several enzymes, among which xylanases (EC 3.2.1.8) play a key role. Xylanase hydrolyzes xylan fibers to shorter sugar residues which have wide applications in industry (Goulart et al., 2005). Recently, interest in xylanases has markedly increased due to their potential applications in the food and 
beverage industries, feedstock improvement and the quality improvement of lignocellulosic residues (Pal and Khanum, 2011). Single enzyme nanoparticles are a recent area of research in industrial enzymes. Nanoparticles are used as a emerging tool for the drug delivery system (Priya VP et al., 2013). Gold nanoparticles can be synthesized by the methods of Arockiya Aarthi Rajathi F et al., 2012; Stalin Dhas T et al., 2012; Venkatachalam M et al., 2013 and Kathick V et al., 2012 and can be used for xylanase immobilization studies. Enzyme immobilization helps in increasing the stability of the enzyme and thus helps in increasing the practical application of enzymes.

Filamentous fungi are useful producers of xylanase because they are capable of producing high levels of extracellular enzymes and can be cultivated very easily. On an industrial scale, xylanases are produced mainly by Aspergillus and Trichoderma spp. in solid state fermentation (SSF) (Pal and Khanum, 2010). Many reports on xylanases from Bacillus spp., Streptomyces spp., Aspergillus spp., Trichoderma spp., and other microorganisms are available (Krisana et al., 2005; Evstatieva et al., 2010). Trichoderma harzianum is present in all soil types and are the most prevalent culturable fungi. This organism has a potential application in the field of biotechnology. Its metabolites stimulate seed germination, plant growth and early flowering and fruit formation. It is also used as a bio-organic fertilizer (Chen LH et al., 2012; Akladious SA et al., 2014), bio-control agent against chickpea (Jayalakshmi SK et al., 2009), reducing root rot disease in tobacco seedlings (Gveroska B and Ziberoski J, 2011), production of industrial enzymes like xylanases (Ahmed $\mathrm{S}$ et al., 2012), celluloytic complexes (Benoliel B et al., 2013), $\beta$-1,3-glucanases (Giese EC et al., 2005).

Sunflower (Helianthus annuus) is cultivated worldwide mainly for oil extraction. Sunflower oil Sludge (a by-product rendered by the oil industry) has been generated in large quantities and remains as waste. Fractionation of Sunflower oil Sludge results in a lignocellulosic fraction (LCF) - 23.2-25.3\%, a proteinaceous fraction (PF) $55.4-57.6 \%$ and a soluble fraction (SF) $17.1-21.4 \%$ of the dry weight. As evidenced by the growth of different fungi, Sunflower oil Sludge -LCF (obtained after removal of PF) was found to be a suitable fermentation source for SSF (Bautista et al., 1990).

Rapid industrialization for sustaining economic stability leads to the pollution of the environment. Industrialization and urbanization are responsible for air, soil and water pollution. To remove pigments, objectionable odors and non-triglyceride material from crude oil, various methods such as bleaching, deacidification, neutralization and odorization were used (Anderson, 1953). An eloquent amount of by-products such as deodorizer distillates, soap stocks, and acidic water are produced from crude oil refining processes, which are potentially harmful to the environment. If these residues are not disposed properly, it could lead to environmental damage representing a danger to all forms of life.

There have been many studies on the biodegradation of various aromatic hydrocarbons, using micro-organisms isolated from the oil residues. Researchers have proved the potential of isolated microbes that has the ability to bio remediate oil polluted environments.

The present study is to explore the potential of a fungal species isolated from fouled soil around an oil refinery in a different endeavor. The fungus isolated is being used for the xylanase enzyme production. The principal aim of this study was to isolate, identify, characterize the fungal strain capable of producing xylanase enzyme from fouled soil around oil refinery and the purification of xylanase produced by the fungal strain. Thus, the isolated filamentous fungal strain is used as a potential enzyme producer from the industrial waste sunflower oil sludge.

\section{Materials and Methods}

\section{Isolation and identification of fungal strain}

To isolate fungal strain, the samples were isolated from soil around oil refinery. $1 \mathrm{~g}$ of sample was dissolved in $10 \mathrm{~mL}$ of sterilized distilled water, serially diluted upto $10^{-6}$ and plated onto Potato Dextrose Agar (PDA) medium containing (component $\mathrm{g} / \mathrm{L}$ ) potato infusion (infusion from 200 g potatoes), 4; dextrose, 20; agar, 15. After sterilization, the medium was supplemented with $10 \mu \mathrm{g}$ amphotericin $/ \mathrm{mL}$ and $25 \mu \mathrm{g}$ streptomycin/mL (Himedia, Mumbai, India) to inhibit fungal and bacterial contamination respectively. The medium was incubated at $35^{\circ} \mathrm{C}$ for $72 \mathrm{~h}$. One plate was kept as an uninoculated control. Pure colonies were isolated by subculturing on PDA. Stock cultures were maintained at $4{ }^{\circ} \mathrm{C}$. Colonies having zone formation were subcultured in potato dextrose broth. The spore morphology was determined by light microscopy and scanning electron microscopy.

\section{Extraction of fungal genomic DNA}

The colonies grown on agar plates were recovered from the surface and placed into $1 \mathrm{~mL}$ of sterilized water and frozen in liquid nitrogen. Cell disruption was done in an ultra-turrax T25 apparatus. The extraction of DNA and its purification was performed as follows: Precipitation of proteins and polysaccharides was done by the addition of Potassium acetate $(5 \mathrm{M})$. The supernatant was filtered on Whatman filter paper and $1 \mathrm{~mL}$ of isopropanol was added to the tube and mixed. Centrifugation at $9600 \times \mathrm{g}$ at $4{ }^{\circ} \mathrm{C}$ for $30 \mathrm{~s}$ was performed. The supernatant was discarded and the pellet (DNA) was dissolved in $70 \mathrm{~mL}$ Tris-HCl $50 \mathrm{mM} \mathrm{pH}$ 8, EDTA $100 \mathrm{mM} \mathrm{pH} \mathrm{8.} \mathrm{After} \mathrm{purification} \mathrm{with} \mathrm{phenol,}$ chloroform and isoamyl alcohol (25:24:1), the upper phase was transferred in a separate tube and added $0.10 \mathrm{~mL}$ of sodium acetate $3 \mathrm{M}$ and $0.7 \mathrm{~mL}$ of isopropanol. After a centrifugation at $9600 \times g$ for $30 \mathrm{~s}$, the supernatant was 
carefully removed and the pellet was dissolved in $40 \mathrm{~mL}$ of Tris-HCl 50 mM, EDTA 100 mM, pH 8.

\section{Classic and molecular identification of fungal strain}

Amplification a 581-bp fragment within the gene coding for the small ribosomal subunit (18S rRNA) of fungi was performed in a Thermal Cycler Gene Amp PCR System 9700 (PE Applied Biosystems, Norwalk, USA) using the fungus specific primers TR1 5'-GTTTCTAGGA CCGCCGTA-3' and TR2 5'-CTCAAACTTCCATCGA CTTG-3' (Bock et al., 1994). Two thermal amplification cycles were used to amplify the fungal $18 \mathrm{~S}$ rDNA. The first cycling parameters were as follows: an initial denaturation step of $96^{\circ} \mathrm{C}$ for $10 \mathrm{~min}$, followed by 30 cycles of $96^{\circ} \mathrm{C}$ for $1 \mathrm{~min}$, annealing at $46^{\circ} \mathrm{C}$ for $1 \mathrm{~min}$ and extension at $72{ }^{\circ} \mathrm{C}$ for $2 \mathrm{~min}$, with a final extension step of $72^{\circ} \mathrm{C}$ for $5 \mathrm{~min}$. Cycle 2 parameters were as follows: denaturation step of $95^{\circ} \mathrm{C}$ for $3 \mathrm{~min}$ followed by 35 cycles of $95^{\circ} \mathrm{C}$ for $1 \mathrm{~min}$ (denaturation), $53{ }^{\circ} \mathrm{C}$ for $1 \mathrm{~min}$ (annealing), $72^{\circ} \mathrm{C}$ for $2 \mathrm{~min}$ (extension) and final extension of $72{ }^{\circ} \mathrm{C}$ for $3 \mathrm{~min}$. The amplification products were verified by electrophoresis in $0.8 \% \mathrm{w} / \mathrm{v}$ agarose gel and DNA stained with ethidium bromide.

The sequences of $18 \mathrm{~S}$ rDNA were obtained using the primer TR2 and ABI PRISM ${ }^{\mathrm{TM}}$ dye terminator cycle sequencing kit (PE Biosystem). The reaction products were analyzed using an Applied Biosystem 373A automated DNA sequencer (Perkin Elmer).

\section{Sequence and phylogenetic analysis}

The sequences were aligned using CLUSTAL W and CLUSTAL X, which is a graphical user interface program and then the sequences were compared with those from GenBank using BLAST (Thompson et al., 1994). Standard Biochemical tests were also performed to identify the genus. The 18SrRNA sequence analysis of the isolate was also performed. The sequence was analyzed using MEGA 5 and the corresponding phylogenetic tree was constructed (Naveena B et al., 2012).

\section{Growth pattern of fungal strain}

Hypocrea lixii SS1 was grown in the growth medium. The temperature and $\mathrm{pH}$ of the medium were maintained at $35{ }^{\circ} \mathrm{C}$ and 5.5 respectively. Absorbance values of cell suspensions were read at $540 \mathrm{~nm}$ at regular intervals of $3 \mathrm{~h}$, over a $192 \mathrm{~h}$ period. Cell cultures were shaken well for $60 \mathrm{~s}$ before each measurement. The control flask contained only the culture medium. The experiments were carried out as triplicates and their average values were taken into consideration.

\section{Determination of growth kinetics}

Samples were collected at every $3 \mathrm{~h}$ interval from the culture flask and subjected for centrifugation at $1118 \mathrm{xg}$ separately. The initial weight of the aluminum foil was taken. The pellet obtained was placed in the foil and kept at $55^{\circ} \mathrm{C}$ for $10 \mathrm{~min}$ until got dried. The weight of the foil with the dried pellet was measured (Naveena B et al., 2012). From the biomass data obtained at various time intervals, the specific growth rate, $\mu_{m}$ and lag time were calculated using modified Gompertz model.

$\ln \left(\frac{X}{X_{0}}\right)=\ln \left(\frac{X_{\max }}{X_{0}}\right) \exp \left(-\exp \left(\frac{\mu_{m} e}{\ln \left(\frac{X_{\max }}{X_{0}}\right)}(\lambda-t)+1\right)\right)$

where $X_{0}, X_{\max }, X, t, \mu_{m}$ and $\lambda$ denote initial biomass concentration $(\mathrm{mg} / \mathrm{mL})$, maximum biomass concentration $(\mathrm{mg} / \mathrm{mL})$ and biomass concentration $(\mathrm{mg} / \mathrm{mL})$, incubation time $(\mathrm{h})$, maximum specific growth rate $\left(\mathrm{h}^{-1}\right)$ and lag time (h), respectively.

\section{Production of xylanase using newly isolated strain}

Isolates were screened for the production of xylanase enzyme using the medium containing (component $\mathrm{g} / \mathrm{L}$ ) Peptone, 1.0; $\mathrm{KH}_{2} \mathrm{PO}_{4}, \quad 2.00 ; \quad \mathrm{MgSO}_{4} .7 \mathrm{H}_{2} \mathrm{O}, \quad 0.30$; $\mathrm{CaCl}_{2} .2 \mathrm{H}_{2} \mathrm{O}, \quad 0.30 ; \quad \mathrm{FeSO}_{4}, 0.01 ;\left(\mathrm{NH}_{4}\right)_{2} \mathrm{SO}_{4}, \quad 1.80$; $\mathrm{ZnSO}_{4} .7 \mathrm{H}_{2} \mathrm{O}, 0.0012 ; \mathrm{MnSO}_{4} \cdot \mathrm{H}_{2} \mathrm{O}, 0.0015$; Sunflower oil Sludge (sole carbon source), 10 and Agarose, 15. Each plate was supplemented with $0.5 \mathrm{~mL}$ of xylan. Fresh fungal spores from the stock culture were inoculated in the plate and incubated at $35^{\circ} \mathrm{C}, \mathrm{pH} 5.5$, moisture content $70 \%$ for 7 days under static condition.

\section{Enzyme assay and protein determination}

Assay for xylanase was performed using $0.5 \%$ soluble birchwood xylan (sigma) in $50 \mathrm{mM}$ sodium phosphate buffer, $\mathrm{pH}$ 7. The reaction mixture was composed of $1.5 \mathrm{~mL}$ substrate and $0.5 \mathrm{~mL}$ crude enzyme. The mixture was incubated in water bath at $45^{\circ} \mathrm{C}$ for $15 \mathrm{~min}$. The released reducing sugar was measured by the dinitrosalicylic acid (DNS) method (Khanna and Gauri, 1993; Miller, 1959). The absorbance was measured at $540 \mathrm{~nm}$ with xylose as the standard. The amount of reducing sugar was calculated from the standard curve based on the equivalent xylose units. One unit of xylanase activity was described as the amount of enzyme producing $1 \mu$ mole of reducing sugar per $\mathrm{mL}$ medium per min under standard test conditions.

The protein content was determined by the method of Bradford method (Lowry et al., 1954). The protein content in the chromatographic fractions was estimated by measuring the absorbance at $280 \mathrm{~nm}$.

\section{Molecular weight determination of xylanase by SDS-PAGE}

The molecular mass of the crude enzyme extract and partially purified xylanase was estimated by SDS-PAGE electrophoresis. SDS-PAGE $(12 \%)$ was performed as described by $\mathrm{Ou}$ et al. (2011). using medium range (10 to 
$100 \mathrm{kDa}$ ) molecular weight markers (Banglore Genei Pvt., India). Xylanase and other proteins were visualized by staining the gel with Coomassie brilliant blue.

\section{Four step purification for xylanase enzyme}

Xylanase (crude) enzyme was subjected to $0-50 \%$ ammonium sulphate precipitation and stored at $4{ }^{\circ} \mathrm{C}$ for overnight. This mixture was centrifuged at $10285 \mathrm{x}$ g for a period of $15 \mathrm{~min}$. The precipitate obtained was dissolved in Tris-HCl buffer ( $20 \mathrm{mM}, \mathrm{pH} 8.0)$. The resultant fraction was dialyzed against Tris- $\mathrm{HCl}$ buffer $(20 \mathrm{mM}, \mathrm{pH}$ 8.0) using cellulose tubing (molecular mass cut-off $10 \mathrm{kDa}$ ) for a period of $24 \mathrm{~h}$ with repeated buffer changes. This step was carried out mainly to make the fraction free from sulphate ions. Further concentration of dialysate was carried out, by dialyzing the resultant fraction against sucrose. This was applied to the DEAE-sepharose column $(2.6 * 10 \mathrm{~cm})$. The column was equilibrated with Tris- $\mathrm{HCl}$ buffer $(20 \mathrm{mM}$, pH 8.0). Elution of the bound proteins were carried out with the linear gradient of $\mathrm{NaCl}(0-0.4 \mathrm{M})$ in the Tris- $\mathrm{HCl}$ buffer ( $20 \mathrm{mM}, \mathrm{pH}$ 8.0).with the flow rate of $30 \mathrm{~mL} / \mathrm{h} .3 \mathrm{~mL}$ fractions were collected. These fractions were tested for xylanase activity and those showing xylanase activity were pooled together. The pooled fraction was again subjected to dialysis against Tris- $\mathrm{HCl}$ buffer $(20 \mathrm{mM}, \mathrm{pH}$ 8.0) for 16-18 $\mathrm{h}$. The resultant dialysate was concentrated further and applied to Sephacryl S-200 $(1.6 * 80 \mathrm{~cm})$ column. Elution of proteins was carried out using Tris-HCl buffer $(20 \mathrm{mM}, \mathrm{pH} 8.0)+0.15 \mathrm{M} \mathrm{NaCl}$ with a flow rate of $20 \mathrm{~mL} / \mathrm{h}$. $2 \mathrm{~mL}$ fractions were collected. These fractions were tested for xylanase activity.The fractions showing xylanase activity were pooled together, checked for purity and used for further analysis.

In order to test the purity of xylanase, $0.5 \mathrm{~mL}$ of sample was injected into an analytical RP-HPLC (Waters 600 analytical HPLC system) equipped with an analytical column $(\mathrm{C} 4,250.46 \mathrm{~cm}, 5 \mu \mathrm{m}$, pore size $80 \AA)$. Solvents used for RP-HPLC included solvent A $(0.1 \%$ trifluroacetic acid (TFA) in water) and solvent B ( $0.07 \%$ trifluroacetic acid (TFA) in $95 \%$ acetonitrile). Xylanase was eluted by means of a linear gradient from $90 \% \mathrm{~A}+10 \% \mathrm{~B}$ to $80 \% \mathrm{~A}+20 \%$ $\mathrm{B}$ at a flow rate of $2 \mathrm{~mL} / \mathrm{min}$ for a period of $30 \mathrm{~min}$. This was monitored in a region of 210-400 nm.

\section{Results and Discussion}

\section{Screening of the strain}

A total of 50 strains was screened from the soil around an oil refinery on PDA for the production of xylanase enzyme. Top ten isolates producing the maximum amount of xylanase is listed in the Table 1. Among those, the strains which produced highest enzyme activity was selected and subjected for further studies. The newly isolated strain produces the maximum xylanase enzyme and its activity was found to be $38.90 \mathrm{U} / \mathrm{mL}$. This is found to be
Table 1 - Different isolates of xylanase production.

\begin{tabular}{lccc}
\hline Isolate No & $\begin{array}{c}\text { Dry weight } \\
(\mathrm{mg})\end{array}$ & $\begin{array}{c}\text { Protein } \\
(\mathrm{mg} / \mathrm{mL})\end{array}$ & $\begin{array}{c}\text { xylanase activity } \\
(\mathrm{U} / \mathrm{mL})\end{array}$ \\
\hline SS1 & 9.23 & 3.54 & 38.90 \\
SS2 & 6.98 & 1.09 & 26.71 \\
SS5 & 7.90 & 1.73 & 24.92 \\
SS7 & 8.00 & 0.921 & 20.08 \\
SS10 & 3.89 & 2.93 & 30.09 \\
SS14 & 1.07 & 0.54 & 15.46 \\
SS20 & 2.06 & 0.043 & 9.23 \\
SS23 & 4.64 & 0.0098 & 6.43 \\
SS33 & 8.98 & 0.3956 & 14.32 \\
SS40 & 9.54 & 2.59 & 16.90 \\
SS42 & 5.80 & 1.003 & 13.04 \\
\hline
\end{tabular}

higher than the enzyme activity obtained from Jonesia denitrificans (Nawel et al., 2011), Streptomyces thermocarboxydus subspecies MW8 strain (Chi et al., 2013). This is the first report showing the highest yield of xylanase by the isolated new strain to the best of our knowledge.

\section{Identification of new fungal strain}

\section{Morphological characteristics}

The strain isolated from the soil has the following morphological characetistics: Isolated strain grows at an optimum temperature of $35^{\circ} \mathrm{C}$. The colonies were first found to be transparent and later changed into yellow color. The change in color is mainly due to the pigment production by fungal strain, which is a characteristic feature of fungal species. The fungal strain under microscope was characterized by the effuse conidiation after 3-5 days of growth, whereas the conidiophores aggregations and pustles developed later. Figures 1 and 2 shows the morphological structure of the isolated xylanase producing micro-organism. The microscopical observations were found to be the similar with Castle et al. (1988). This confirms that the new species identified belongs to Hypocrea $s p$. However, these methods are problematic as there are different biotypes within a species and time consuming. Hence 18 s rRNA sequencing was carried out for getting reproducible and accurate results.

\section{Identification of fungal genome}

Genomic identification was carried out by 18 s rRNA sequencing, and the sequence was obtained. This was blasted against the entire microbial genome database in $\mathrm{Na}-$ tional Center for Biotechnology Information (NCBI). The BLAST result showed only $93 \%$ similarity with other existing fungal species and thus was found to be a new strain (named SS1). Hence, this sequence was deposited in the 


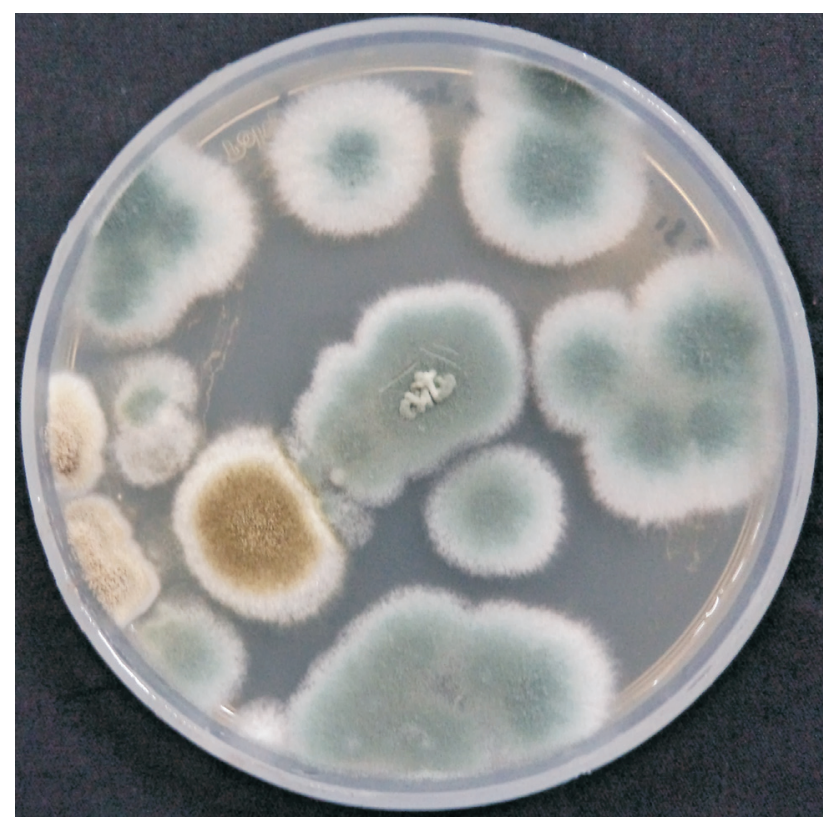

Figure 1 - Morphological structures of isolated Hypocrea lixii SS1.

GenBank and was provided with a new accession number (JN687587).

\section{Phylogenetic tree}

Phylogenetic tree was constructed from neighborjoining program, using bootstrap consensus test with 500 in MEGA 5 and the branch lengths are in the same as those of the evolutionary distances used to infer the phylogenetic tree. The newly isolated strain was closely related to Hypocrea lixii with $96 \%$ similarity. Based on this similarity the isolated new fungal strain was identified as a Hypocrea lixii strain SS1 shown in Figure 3.

\section{Growth pattern of fungal strain}

The growth kinetics of the Hypocrea lixii SS1 obtained by their cultivation from 0 to $192 \mathrm{~h}$ was shown in Figure 4. The biomass data obtained from the growth analy-

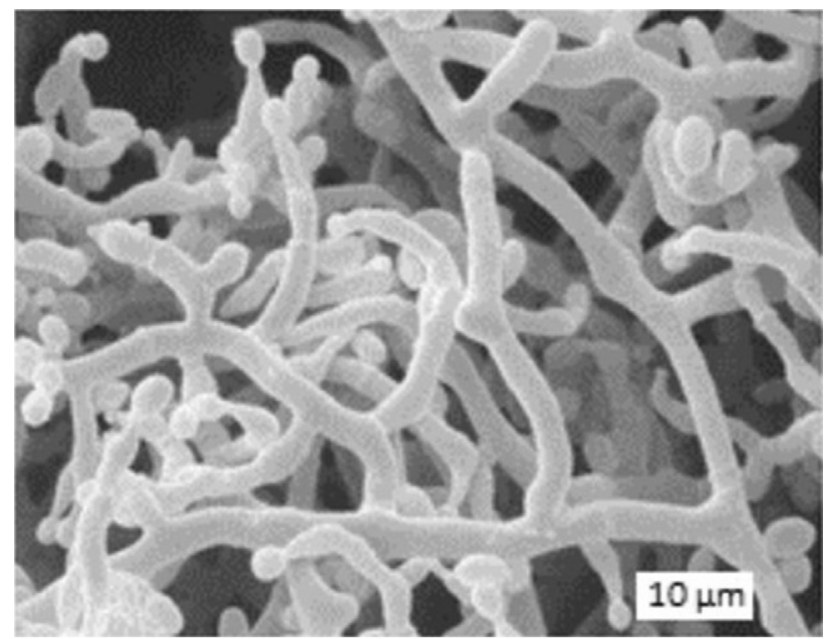

Figure 2 - SEM image of the isolate, Hypocrea lixii SS1.

sis was modeled using modified Gompertz model which was denoted by Eq. (1). The experimental data obtained for the fungal isolate fits into the model using Matlab 7.0. The specific growth rate and the lag time obtained for the fungal isolate was given in Table 2. The exponential growth was observed from $96 \mathrm{~h}$ to $168 \mathrm{~h}$ after which it attains a steady state around $192 \mathrm{~h}$. This implies that the maximum growth observed on the $7^{\text {th }}$ day of incubation. And there was no growth in the uninoculated control which indicates that the biomass obtained on the inoculated medium was only due to the fungal growth.

\section{Production of xylanase enzyme by newly isolated strain}

The newly isolated strain Hypocrea lixii SS1 was able to produce xylanase enzyme using Sunflower oil Sludge as the sole carbon source in the production medium. The strain Hypocrea lixii SS1 utilizes the lignocellulosic waste (Sunflower oil Sludge) with the help of xylanase produced on its own and convert them into xylose units, as described in the biochemical pathway shown in Figure 5 and is similar to re-

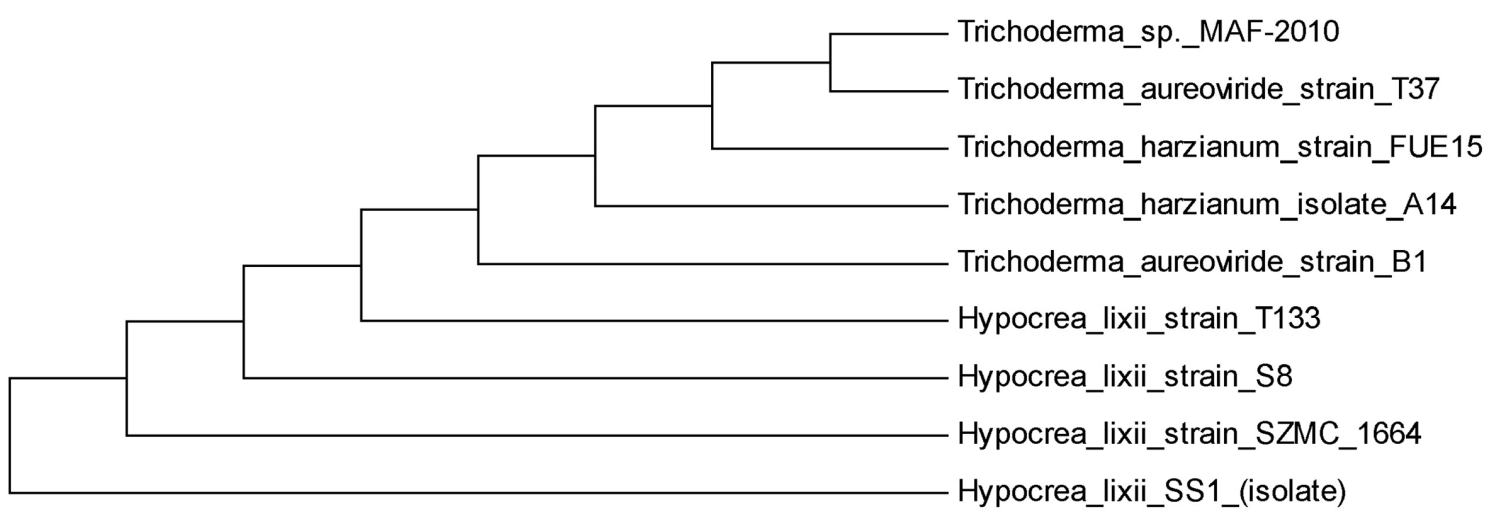

Figure 3 - Neighbour-joining tree based on nearly complete 18S rDNA gene sequences showing relationships between Hypocrea lixii SS1 (isolate) and the related Hypocrea species strain. 


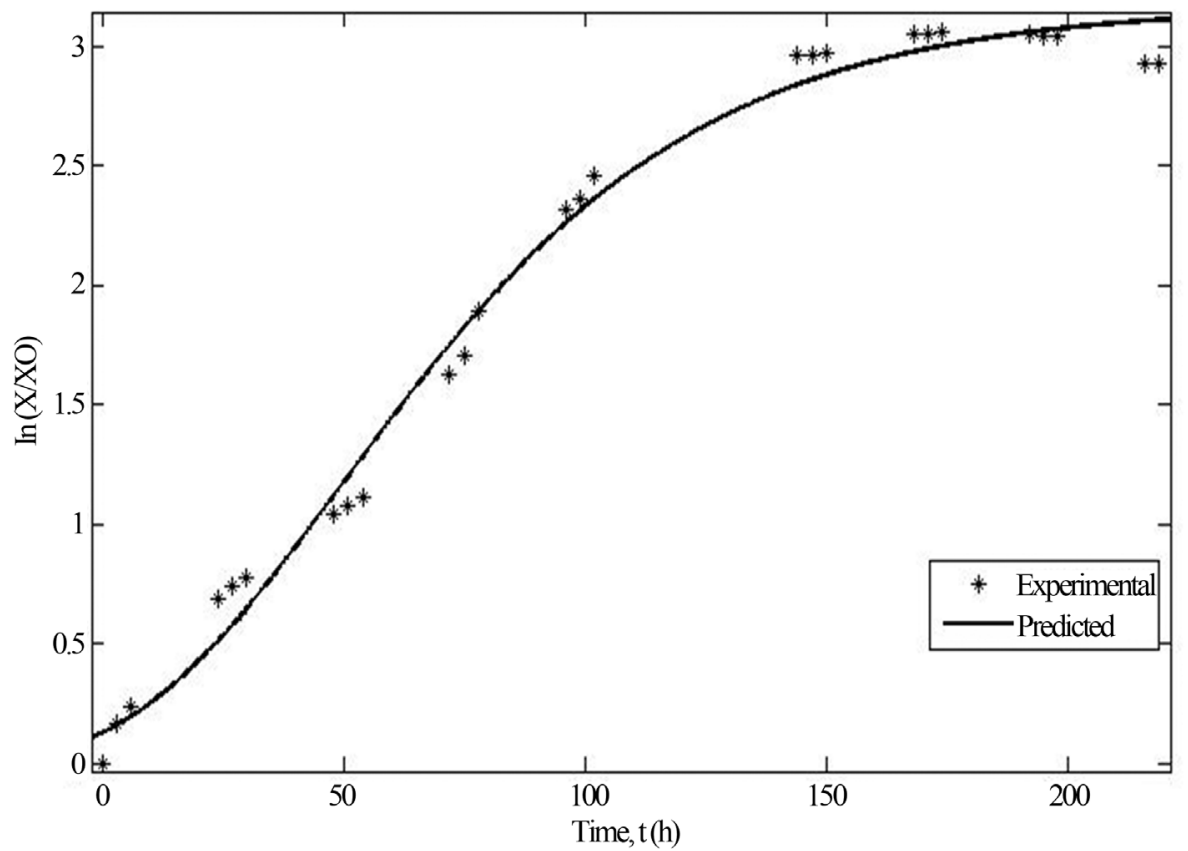

Figure 4 - Growth Kinetics of fungal Hypocrea lixii ss 1.

Table 2 - Determination of Growth Kinetic parameters of Hypocrea lixii SS1.

\begin{tabular}{lccc}
\hline Fungal isolate & $\begin{array}{c}\text { Specific growth } \\
\text { rate, } \mu_{\mathrm{m}}\left(\mathrm{h}^{-1}\right)\end{array}$ & $\begin{array}{c}\text { Lag time, } \\
\lambda(\mathrm{h})\end{array}$ & $\begin{array}{c}\text { Coefficient of } \\
\text { determina- } \\
\text { tion, } \mathrm{R}^{2}\end{array}$ \\
\hline Hypocrea lixii SS1 & 0.032 & 6.932 & 0.989 \\
\hline
\end{tabular}

view by Polizeli MLTM et al., 2005. A maximum yield of $38.90 \mathrm{U} / \mathrm{mL}$ of xylanase was obtained by the isolated strain Hypocrea lixii SS1 in production medium. Singh R et al. (2012) reported a maximum xylanase yield of $30.15 \mathrm{IU} / \mathrm{mL}$ from thermophilic actinomycetes using various agro industrial wastes. Moreira LRS et al. (2012) reported a maximum yield of $0.978 \mathrm{IU} / \mathrm{mL}$ xylanase using a combination of Aspergillus niger on sugarcane baggasse and Emericela nidulans on dirty cotton residue. Gottschalk LMF et al. (2013) reported a maximum yield of $44880 \mathrm{U} / \mathrm{L}$ xylanase along with other enzymes - xylosidase and ferulic acid esterase from Aspergillus awamori 2B.361 U2/1. Moretti MMS et al. (2012) reported a maximum yield of xylanase $1040 \mathrm{U} / \mathrm{g}$ from Aspergillus fumigates M.7.1 and $1292 \mathrm{U} / \mathrm{g}$ from Myceliophthora thermophila M.7.7 using the wastes wheat bran and sugarcane baggasse.

\section{Molecular weight determination of xylanase by SDS-PAGE}

The extracellular enzyme produced by the isolated Hypocrea lixii SS1 was found to be xylanase. This was further confirmed and characterized by SDS-PAGE. The supernatant (crude enzyme) and gel filtration active fraction of supernatant (representing partially purified enzyme) from Hypocrea lixii SS1 culture were used to perform the zymogram analysis. Figure 6 shows the protein content on the SDS-PAGE (Lanes 1, 2, 3). Lane1 \& Lane2 contain the crude enzyme extract and Lane 3 contains the product after the gel filtration procedure. The gel-filtration procedure is proved to be effective for xylanase enzyme purification since Lane 3 shows the predominant band. The results indicate that Hypocrea lixii strain SS1 has the ability to produce xylanase enzyme and its molecular weight was found to be $29 \mathrm{kDa}$. The results obtained were similar to Kamble and Jadhav (2012).

\section{Purification of xylanase enzyme}

Xylanase from H.lixii SS1 was purified using ammonium sulphate precipitation followed by a two-step chromatographic procedure. The results of purification procedures are represented in Table 3 . The crude enzyme had a total activity of $21,580 \mathrm{U}$. After ammonium sulphate precipitation, the enzyme was purified 6.38 fold with $86.32 \%$ recovery. The enzyme was then subjected to DEAEsepharose ion exchange chromatography. In this step, xylanase was purified 24.67 fold with $69.54 \%$ recovery. Finally, xylanase was subjected to Gel filtration chromatography. In this step, xylanase was purified 41.23 fold with $47.9 \%$ recovery. The results obtained in the current study, were found to be better when compared to the studies by others in various microorganisms. Pal A et al. (2011) reported a yield of $38.9 \%$ with a purification fold of 36.97 recovery from Aspergillus niger DFR-5 using ion exchange and gel filtration chromatography. Gaffney M et al. (2009) reported $7.6 \%$ recovery with a purification fold of 9.3 from Thermomyces lanuginosus using a combination of ultra- 


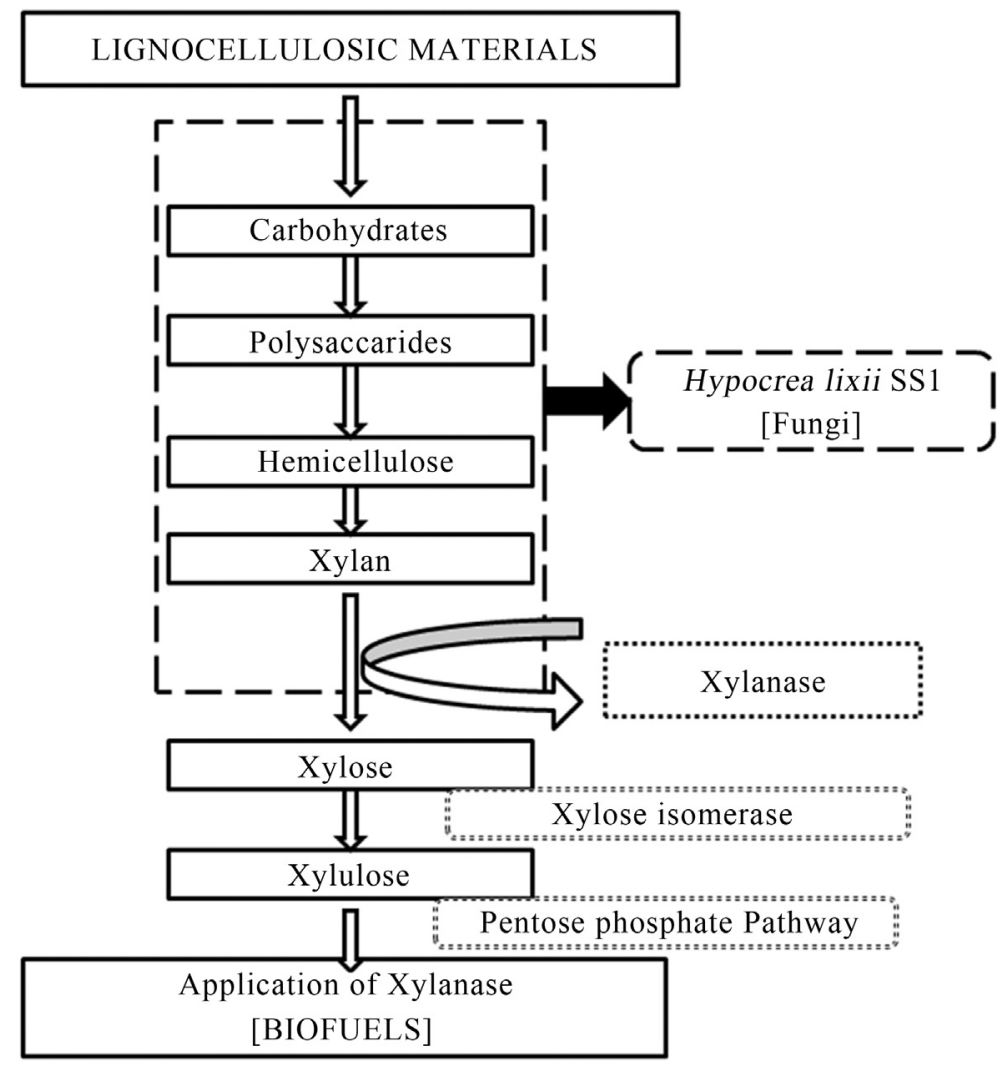

Figure 5 - Biochemical pathway of Xylanase production.

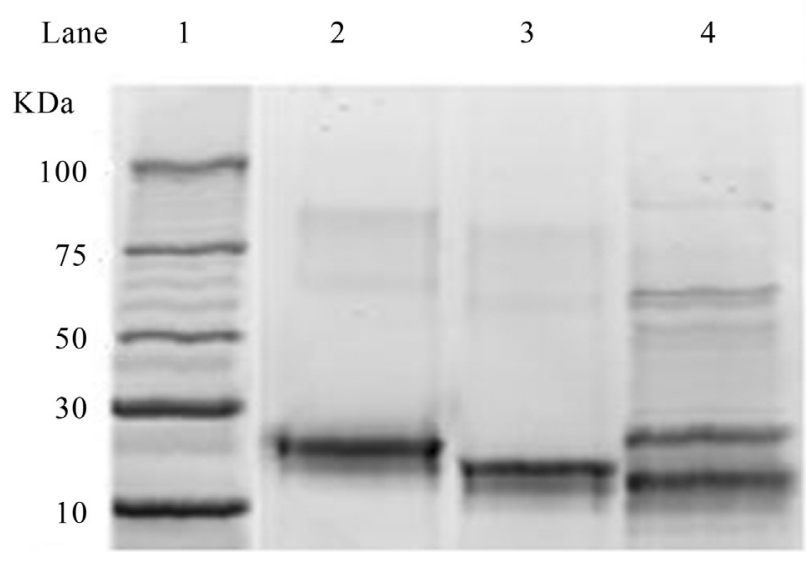

Figure 6 - Estimation of xylanase molecular weight using SDS-PAGE. filtration, anion exchange, gel filtration chromatography. Yang S et al. (2008) reported 34.5\% recovery with a purification fold of 5.8 from Paecilomyces thermophile using a combination of $20-60 \%\left(\mathrm{NH}_{4}\right) \mathrm{SO}_{2}$ concentration, Supradex 75 column chromatography and DEAE 52 column chromatography. Ninawe $\mathrm{S}$ et al. (2008) reported a purification fold of 2.25 with $43.62 \%$ recovery from Streptomyces cyaneus SN32 using a combination of ammonium sulphate concentration and DEAD-sepharose chromatography.

Both crude enzyme and purified xylanse was subjected RP-HPLC method to confirm the purification procedure. The results are represented graphically Figure $7 \mathrm{a}$ and $7 \mathrm{~b}$. Figure $7 \mathrm{a}$, has numerous peaks, showing that the crude extract is heterogeneous containing various protein components along with it. Figure $7 b$, shows a unique peak at $280 \mathrm{~nm}$ (Retention time $16.60 \mathrm{~min}$ ), confirming the purified xylanase is homogeneous indicating the absence of other impurities, thus confirming the purity of xylanse.

Table 3 - Four Step Purification of xylanase.

\begin{tabular}{|c|c|c|c|c|}
\hline Fraction & Total activity (U) & Total protein (mg) & Purification fold & Yield $(\%)$ \\
\hline Crude extract & 21,580 & 5681 & 1 & 100 \\
\hline Ammonium sulphate & 17,810 & 1082 & 6.38 & 86.32 \\
\hline Ion-exchange chromatography & 13,560 & 148 & 24.67 & 69.54 \\
\hline Gel permeation chromatography & 6,480 & 56 & 41.23 & 47.90 \\
\hline
\end{tabular}




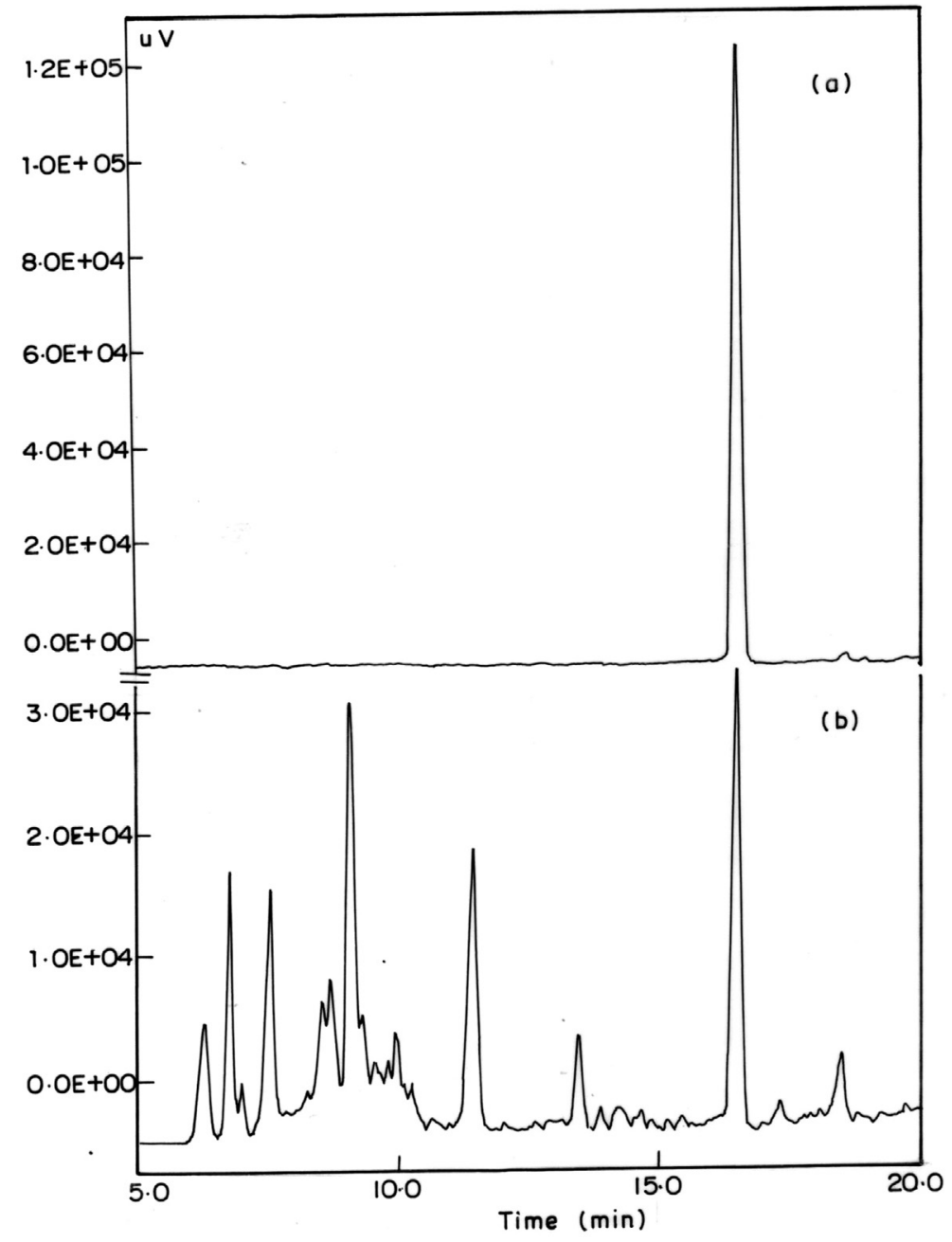

Figure 7 - RP-HPLC analysis of (a) purified enzyme and (b) crude enzyme.

\section{Conclusion}

The present study showed that soil near oil refineries could be a rich source of xylanase enzyme producing fungi using Sunflower oil Sludge as the waste from the oil industry. The following conclusions were made from this study:

Out of various microorganisms isolated from the fouled soil, fungal strain SS1 was found to be high potential for the production of xylanase enzyme.

The genus of the fungal isolate was identified as Hypocrea by performing the morphological and biochemical tests. Furthermore the 18srRNA and the phylogenetic analysis reasserted the isolate as Hypocrea lixii SS1.

A maximum yield of $38.90 \mathrm{U} / \mathrm{ml}$ xylanase was obtained using the isolated strain Hypocrea lixii SS1.

The enzyme was further affirmed by SDS-PAGE with their standard molecular weight $(29 \mathrm{kDa})$.

Xylanase from Hypocrea lixii SS1 was purified to absolute homogeneity using a combination of ammonium sulphate precipitation, DEAE-sepharose ion exchange chromatography and gel filtration chromatography. Single peak was obtained when this preparation was subjected to RPHPLC, confirming the purity of xylanase.

\section{Acknowledgments}

The authors are thankful to M/s. kaleesuwari Refinery Pvt. Ltd., Chennai, India, for providing Sunflower oil sludge for this investigation.

\section{References}

Ahmed S, Imdad S, Jamil A (2012) Comparative study for the kinetics of extracellular xylanases from Trichoderma harzianum and Chaetomium thermophilum. Electron J Biotechno http://dx.doi.org/10.2225/vol15-issue3-fulltext-2.

Akladious SA, Abbas SM (2014) Application of Trichoderma harzianum T22 as a Biofertilizer potential in Maize growth. J Plant Nutr 37:30-49.

Anderson AJC (1953) Refining of Oils and Fats for Edible Purposes. Academic Press, London.

Arockiya Aarthi Rajathi F, Parthiban C, Ganesh Kumar V, Anantharaman P (2012) Biosynthesis of antibacterial gold 
nanoparticles using brown alga, Stoechospermum marginatum (kutzing). Spectrochim Acta A 99:166-173.

Bautista J, Parrado J, Machado A (1990) Composition and fractionation of sunflower meal: Use of the lignocellulosic fraction as substrate in solid-state fermentation. Biol Waste 32:225-233.

BenolielB, Torres FAG, De Moraes LMP (2013) A novel promising Trichoderma harzianum strain for the production of a cellulolytic complex using sugarcane bagasse in natura. Springerplus 2:656.

Bock M, Maiwald M, Kappe R, Nickel P, Nahher H (1994) Polymerase chain reaction-based detection of dermatophyte DNA with a fungus-specific primer system. Mycoses 37:79-84 9 .

Castle A, Speranzini D, Rghei N, Alm G, Rinker D, Bissett J (1988) Morphological and molecular identification of trichoderma isolates on north American mushroom farms. Appl. Environ. Microbiol 64:133-137.

Chen LH, Huang XQ, Zhang FG, Zhao DK, Yang XM (2012) Application of Trichoderma harzianum SQR-T037 bio-organic fertiliser significantly controls Fusarium wilt and affects the microbial communities of continuously cropped soil of cucumber. J Sci Food Agric 92:2465-2470.

Chi WJ, Lim JH, Park DY, Park JS, Hong SK (2013) Production and characterization of a thermostable endo-type $\beta$-xylanase produced by a newly-isolated Streptomyces thermocarboxydus subspecies MW8 strain from Jeju Island. Process Biochem http://dx.doi.org/10.1016/j.procbio.2013.07.024.

Evstatieva Y, Nikolova D, Ilieva S, Getov L, Savov V (2010) Identification and characterization of $\alpha$-amylase and endoxylanase, produced by Aspergillus mutant strains. Biotechnol Biotechnol Equip 4:613-7.

Foyle T, Jennings L, Mulcahy P (2007) Compositional analysis of lignocellulosic materials: Evaluation of methods used for sugar analysis of waste paper and straw. Bioresour Technol 98:3026-3036.

Gaffney M, Carberry S, Doyle S, Murphy R (2009) Purification and Characterisation of a Xylanase from Thermomyces Lanuginosus and Its Functional Expression by Pichia Pastoris. Enzyme Microb Technol 45:348-54.

Giese EC, Covizzi LG, Borsato D, Dekker RFH, Da Silva MDLC, Barbosa AM (2005) Botryosphaeran, a New Substrate for the Production of $\beta$-1,3-glucanases by Botryosphaeria Rhodina and Trichoderma harzianum Rifai. Process Biochem 40:3783-3788.

Gottschalk LMF, Paredes RDS, Teixeira RSS, Silva ASA, Silva Bon EP (2013) Efficient production of lignocellulolytic enzymes xylanase, $\beta$-xylosidase, ferulic acid esterase and $\beta$-glucosidase by the mutant strain Aspergillus awamori 2B.361 U2/1. Braz J Microbiol 44:569-576.

Goulart AJ, Carmona EC, Monti R (2005) Partial purification and properties of cellulase-free alkaline xylanase produced by Rhizopus stolonifer in solid-state fermentation. Braz Arch Biol Technol 48:327-33.

Gveroska B, Ziberoski J (2011) The influence of Trichoderma harzianum on reducing root rot disease in tobacco seedlings caused by Rhizoctonia solani. Int J Pure Appl Sci Technol 2:1-11.

Howard RL, Abotsi E, Rensburg ELJ, Howard S (2003) Lignocellulose biotechnology: issues of bioconversion and enzyme production Review. Afr. J. Biotechnol 2:602-619.
Jayalakshmi SK, Raju S, Usha Rani S, Benagi VI, Sreeramulu K (2009) Trichoderma harzianum L1 as a potential source for lytic enzymes and elicitor of defense responses in chickpea (Cicer arietinum L.) against wilt disease caused by Fusarium oxysporum f. sp. ciceri. Aust J Crop Sci 3:44-52.

Kamble RD, Jadhav AR (2012) Isolation, Purification, and Characterization of Xylanase Produced by a New Species of Bacillus in Solid State Fermentation. Int. J. Microbiol Article ID 683193.

Karthick V, Ganesh Kumar V, Maiyalagan T, Deepa R, Govindaraju K, Rajeswari A, Stalin Dhas T (2012) Green Synthesis of Well Dispersed Nanoparticles using Leaf Extract of Medicinally useful Adhatoda Vasica Nees. Micro and Nanosystems 4:192-198.

Khanna S, Gauri (1993) Regulation, purification and properties of xylanase from Cellulomonas fimi. Enzyme Microb Technol 15:990-5.

Krisana A, Rutchadaporn S, Jarupan G, Lily E, Sutipa T, Kanyawim K (2005) Endo-1,4- $\beta$ - xylanase from Aspergillus cf. niger BCC 14405 isolated in Thailand: purification, characterization and gene isolation. Biochem Mol Biol 38:17-23.

Lowry OH, Rosebrough NJ, Farr AL, Randall RJ (1951) Protein Measurement with the Folin Phenol Reagent. J Biol Chem 193:265-275.

Miller GL (1959) Use of dinitrosalicilic acid reagent for determination of reducing sugar. Anal Chem 31:426-428.

Moreira LRS, Ferreira GV, Santos SST, Ribeiro APS, Siqueira FG, Filho EXF (2012) The hydrolysis of agro-industrial residues by holocellulose-degrading enzymes. Braz J Microbiol 43:498-505.

Moretti MMS, Martins DAB, Silva1 RD, Rodrigues A, Sette LD, Gomes E (2012) Selection of Thermophilic and Thermotolerant Fungi for the Production of Cellulases and Xylanases under Solid-state Fermentation. Braz J Microbiol 43:1062-1071.

Mtui GYS (2009) Recent advances in pretreatment of lignocellulosic wastes and production of value added products Review. Afr J Biotechnol 8:1398-1415.

Naveena B, Sakthiselvan P, Elaiyaraju P, Partha N (2012) Ultrasound induced production of thrombinase by marine actinomycetes: Kinetic and optimization studies. Biochem Eng J 61:34-42.

Nawel B, Said B, Estelle C, Hakim H, Duchiron F (2011) Production and partial characterization of xylanase produced by Jonesia denitrificans isolated in Algerian soil. Process Biochem 46:519-525.

Ninawe S, Kapoor M, Kuhad RC (2008) Purification and characterization of extracellular xylanase from Streptomyces cyaneus SN32. Bioresour Technol 99:1252-1258.

Okafor UA, Okochi VI, Onyegeme-okerenta BM, NwodoChinedu S (2007) Xylanase production by Aspergillus niger ANL 301 using agro-wastes. Afr J Biotechnol 6:1710-1714.

Ou S, Zhang J, Wang Y, Zhang N (2011) Production of Feruloyl Esterase from Aspergillus niger by Solid-State Fermentation on Different Carbon Sources. Enzyme Res Article ID 848939, doi:10.4061/2011/848939.

Pal A, Khanum F (2010) Production and extraction optimization of xylanase from Aspergillus niger DFR-5 through solidstate-fermentation. Biores Technol 101:7563-9.

Pal A, Khanum F (2011) Identification and optimization of critical medium components using statistical experimental de- 
signs for enhanced production of xylanase from Aspergillus flavusDFR-6. Food Technol Biotechnol 49:228-236.

Pal A, Khanum F (2011) Purification of Xylanase from Aspergillus niger DFR-5: Individual and Interactive Effect of Temperature and $\mathrm{pH}$ on its Stability. Process Biochem 46:879-87.

Pandey A, Soccol CR, Poonam Nigam P, Soccol VT (2000) Biotechnological potential of agro-industrial residues. I: sugarcane bagasse. Bioresour Technol 74:69-80.

Polizeli MLTM, Rizzatti ACS, Monti R, Terenzi HF, Jorge JA, Amorim DS (2005) Xylanases from fungi: properties and industrial applications. Appl Microbiol Biotechnol 67:577591.

Priya PV, Tejal GS, Vaishali TT, Tejal RG (2013) Nanoparticle as An Emerging Tool in Pulmonary Drug Delivery System. Micro and Nanosystems 5:288-302. $10.2174 / 18764029113059990002$.

Shallom D, Shoham Y (2003) Microbial hemicellulases. Curr Opin Microbiol 6:219-28.

Singh R, Kapoor V, Vijay Kumar (2012) Utilization of Agroindustrial Wastes for the Simultaneous Production of Amy- lase and Xylanase by Thermophilic Actinomycetes. Braz J Microbiol 43:1545-1552.

Stalin Dhas T, Ganesh Kumar V, Stanley Abraham L, Karthick V, Govindaraju K (2012) Sargassum myriocystum mediated biosynthesis of gold nanoparticles. Spectrochim Acta A 99:97-101.

Thompson JD, Higgins DG, Gibson TJ (1994) CLUSTAL W: Improving the sensitivity of progressive multiple sequence alignment through sequence weighting, position specific gap penalties and weight matrix choice. Nucleic Acid Res 22:4673-80.

Venkatachalam M, Govindaraju K, Mohamed Sadiq A, Tamilselvan S, Ganesh Kumar V, Singaravelu G (2013) Functionalization of gold nanoparticles as antidiabetic nanomaterial. Spectrochim Acta A 116:331-338.

Yang S, Huang Z, Jiang Z, Li L (2008) Partition and Purification of a Thermostable Xylanase Produced by Paecilomyces Thermophila in Solid-state Fermentation Using Aqueous Two-phase Systems. Process Biochem 43:56-61.

All the content of the journal, except where otherwise noted, is licensed under a Creative Commons License CC BY-NC. 